\title{
The Deoxidation Ability of Silicon in the Molten Stainless Steel*
}

\section{By Takeya TOGE** and Tetsuya WATANABE**}

\section{Synopsis}

$\mathrm{Si}$ is a prime deoxidizing element for stainless steel deoxidation practice. It is considered that the deoxidizing ability of $\mathrm{Si}$ may be increased by reducing $a_{\mathrm{SiO}_{2}}$. This effect, however, has not been understood clearly.

From this viewpoint, the authors have investigated the $\mathrm{Si}-\mathrm{O}$ equilibrium for $18 \mathrm{Cr}-8 \mathrm{Ni}$ melt, and furthermore measured the effect of crucible materials and that of slag composition on the deoxidation power of $\mathrm{Si}$.

The results are summarized as follows:

(1) The experimental equations for $\mathrm{Si}-\mathrm{O}$ deoxidation equilibrium for $18 \mathrm{Cr}-8 \mathrm{Ni}$ stainless melt are given as follows;

$$
\begin{aligned}
& \log K_{\mathrm{Si}}=-19690 / T+5.914 \pm 0.041 . \\
& \log K_{\mathrm{Si}}=-31740 / T+12.347 \pm 0.041
\end{aligned}
$$

using the following interaction coefficients:

$$
\begin{aligned}
& e_{\mathrm{Si}}^{\mathrm{C}}=0.25, \quad e_{\mathrm{Si}}^{\mathrm{Si}}=3910 / T-1.77, \quad e_{\mathrm{Si}}^{\mathrm{Ni}}=0.007, \\
& e_{\mathrm{Si}}^{\mathrm{Cr}}=0, \quad e_{\mathrm{S} 1}^{\mathrm{O}}=-0.24, \quad e_{0}^{\mathrm{C}}=-0.421, \quad e_{0}^{\mathrm{Si}}=-0.137, \\
& e_{\mathrm{O}}^{\mathrm{Ni}}=0.005, \quad e_{\mathrm{O}}^{\mathrm{O}}=-1750 / T+0.76, \quad \log _{0}^{\mathrm{Cr}}=-0.040[\% \mathrm{Cr}] \\
& \left(\begin{array}{l}
\text { for } E q .(1)) \\
\quad \log _{0}^{\mathrm{Cr}}=-(369 / T-0.137)[\% \mathrm{Cr}]+0.0024[\% \mathrm{Cr}]^{1.75}
\end{array}\right.
\end{aligned}
$$

(for Eq. (2))

The value of $\log K_{\mathrm{Si}}$ at $1600^{\circ} \mathrm{C}$ agrees well with that of the equation for $\mathrm{Fe}-\mathrm{Si}-\mathrm{O}$ system recommended by the 19th Committee of Japan Society for the Promotion of Science.

(2) As to the effect of crucible materials on the deoxidation power of $\mathrm{Si}$, it increases when using $\mathrm{CaO}$ and $\mathrm{CaO}-\mathrm{SiO}_{2}$ crucible, and the effect of $\mathrm{Al}_{2} \mathrm{O}_{3}$ crucible is considerably small.

The effect of $\mathrm{MgO}$ and $\mathrm{ZrO}_{2}$ crucibles is intermediate.

(3) The deoxidation equilibrium of $\mathrm{Si}$ with $\mathrm{CaO}-\mathrm{SiO}_{2}-\mathrm{Al}_{2} \mathrm{O}_{3}$ (sat.) slag has been measured at $1600^{\circ} \mathrm{C}$, and the relation between the $(\% \mathrm{CaO})$ $\left(\% \mathrm{SiO}_{2}\right)$ and $a_{\mathrm{SiO}_{2}}$ was determined. The result shows that the oxygen concentration on silicon deoxidation is greatly influenced by the basicity of co-existing slag and that the observed values of $a_{\mathrm{SiO}_{2}}$ are larger than the estimation from the slag composition.

(4) The above mentioned results lead to the conclusion that the deoxidation power of $\mathrm{Si}$ in actual stainless steel melt is enhanced by using basic slag. However, it seems to be difficult to attain the equilibrium oxygen concentration expected from the slag composition.

\section{Introduction}

In the stainless steel making operation, such elements as $\mathrm{Si}, \mathrm{Al}, \mathrm{Ti}, \mathrm{Ca}$, etc. are generally used for deoxidation alone or in combination. Being most generally used, $\mathrm{Si}$ is known for its characteristic of increasing its deoxidation power in combination with basic slag. In general, the stainless steel making practice uses basic furnaces and the deoxidation process at the final stage of refining is also accomplished in basic slag. Upon tapping, the molten steel is transferred to a ladle together with basic slag. Because of favorable mixing effect of slag and molten metal, the influence of the slag on the deoxidation power of Si cannot be ignored. However, little quantative information is available about this effect. Ramachandran and co-workers ${ }^{1)}$ consider that slag work only as a protective barrier against the oxidation by atmosphere, and rather attach importance to the deoxidation equilibrium with impure silica precipitated from the melt.

In this study, the authors first determined the deoxidation equilibrium of $\mathrm{Si}$ in stainless steel and further confirmed the influence of crucible materials and slag composition on this equilibrium.

\section{Apparatus and Method of Experiment \\ 1. Apparatus}

Schematic drawing of the experimental apparatus is shown in Fig. 1. The Mo-resistance furnace is composed of a $80 \mathrm{~mm}$ furnace core (alumina tube) around which $2 \mathrm{~mm} \phi$ Mo wire with the length of about $18 \mathrm{~m}$ is wound. The load power source is single phase $200 \mathrm{~V}$, and the electrical capacity of the furnace is $8 \mathrm{kVA}$. An alumina tube $(50 \mathrm{mmID} \times 60 \mathrm{mmOD} \times$ $700 \mathrm{mmH}$, supplied by Degssa) was used as the reaction tube. Temperature of the furnace was controlled with SCR voltage regulator by monitoring with an output type PID meter. By this system, the fine adjustment of furnace temperature, for example 1580 $\pm 1^{\circ} \mathrm{C}$, is possible.

A PR18 (Pt-Pt.13\% Rh) thermocouple was inserted from the furnace bottom into the reaction tube, being in contact with the crucible bottom, as shown in Fig. 2. The thermocouples were corrected every

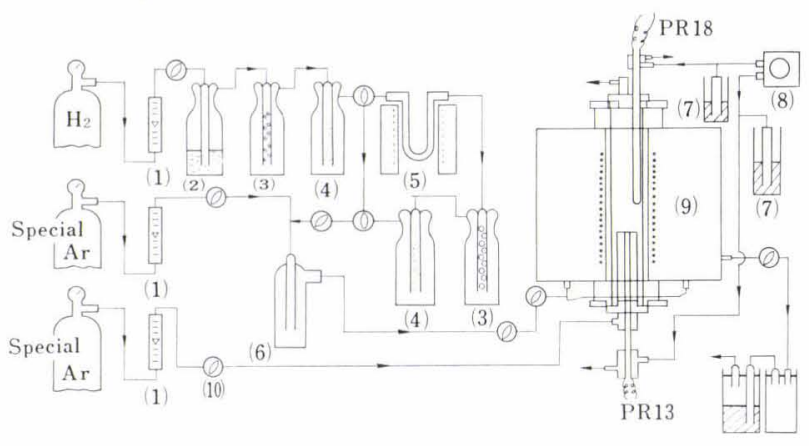
(1) Flowmeter
(6) Gas mixer
(2) Conc. $\mathrm{H}_{2} \mathrm{SO}_{4}$
(3) $\mathrm{CaCl}_{2}$
(4) $\mathrm{P}_{2} \mathrm{O}_{5}$
(7) Bleeder
(8) Air pump
(5) Pd-asbestos $\left(350^{\circ} \mathrm{C}\right)$
(9) Mo-furnace
(10) Cock

Fig. 1. Schematic diagram of the apparatus

* Originally published in Tetsu-to-Hagané, 60 (1974), 2126, in Japanese. English version received December 25, 1974.

** Kawasaki Works, Nippon Yakin Kogyo Co., Ltd., Kojimacho, Kawasaki-ku, Kawasaki 210. 


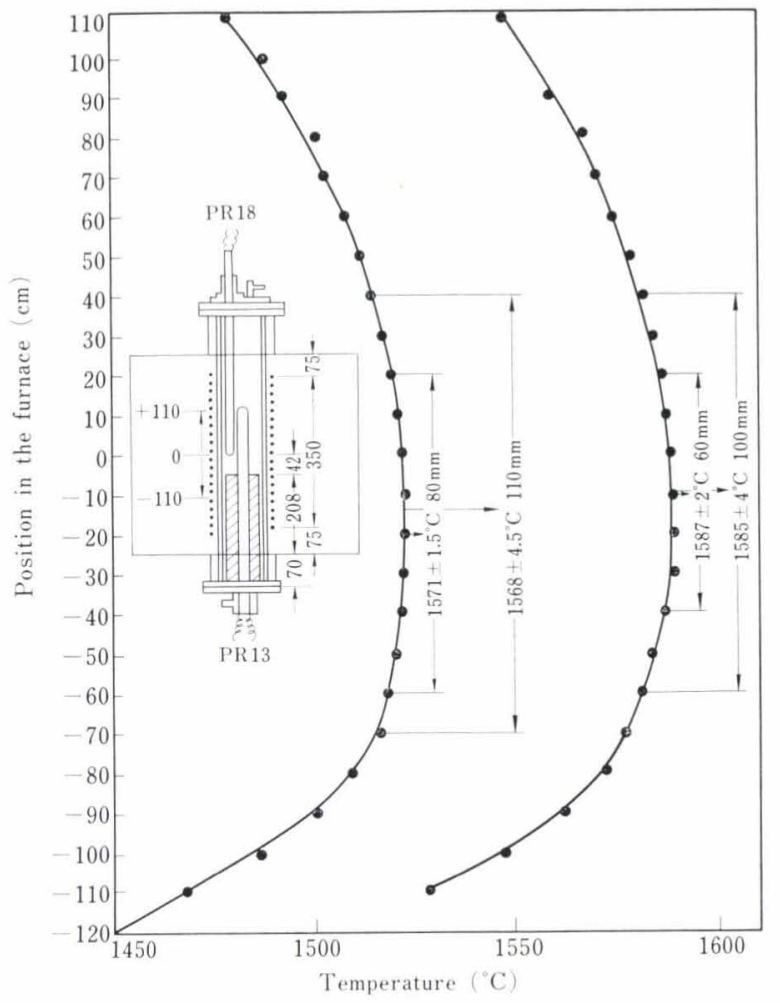

Fig. 2. Temperature distribution in the Mo-furnace

five heat against the Pd melting point. Figure 2 shows the temperature distribution in the reaction tube and Table 1 does the material and dimensions of the crucibles used.

\section{Experimental Method}

A mother alloy of $18 \mathrm{Cr}-8 \mathrm{Ni}$ was prepared by vacuum induction melting, using electrolytic chromium, electrolytic nickel and electrolytic iron. Its typical chemical is the following:

\section{$\begin{array}{llllllllll}\text { C } & \text { Si } & \mathrm{Mn} & \mathrm{P} & \mathrm{Ni} & \mathrm{Cr} & \mathrm{N} & \mathrm{H} & \mathrm{Al}\end{array}$} $\begin{array}{llllllll}0.03 & 0.10 & 0.05 & 0.010 & 8.00 & 18.00 & 0.010 & 3\end{array}$ ppm 0.010

The mother alloy and ferric oxide were melted in Ar gas atmosphere, using various crucibles, and after being kept for $15 \mathrm{~min}$ at the designated temperature, Ferro-Si (commercial grade: $64.1 \% \mathrm{Si}$ ) was added and the experiment started. After being maintained for the designated period, the specimen was sucked up with a silica tube, the inside of which had been substituted by $\mathrm{Ar}$ in advance, and rapidly cooled in water for chemical analysis.

The equilibration time was set 1 to $1 \frac{1}{2} \mathrm{hr}$ longer than that taken for the oxygen concentration and the value of $[\mathrm{Si}] \cdot[\mathrm{O}]^{2}$ to become constant. The weight of melts was 100 to $200 \mathrm{~g}$, taking the crucible dimensions into consideration.

The method of chemical analysis and its accuracy for each element are shown in Table 2.

\section{Results and Discussions}

\section{Theoretical Consideration}

The deoxidation equilibrium of Si for stainless steel
Table 1. Crucible dimension

\begin{tabular}{c|c|l}
\hline Kind of material & $\begin{array}{c}\text { Dimension }(\mathrm{mm}) \\
(\mathrm{OD}) \times(\mathrm{ID}) \times(\mathrm{H})\end{array}$ & \multicolumn{1}{|c}{ Remark } \\
\hline $\mathrm{SiO}_{2}$ & $33 \times 30 \times 60$ & Fused silica \\
$\mathrm{Al}_{2} \mathrm{O}_{3}$ & $30 \times 23 \times 150$ & Corundum \\
$\mathrm{MgO}_{\mathrm{ZrO}}$ & $30 \times 24 \times 50$ & Periclase \\
$\mathrm{CaO}$ & $34 \times 28 \times 120$ & Zirconia \\
& $27 \times 16 \times 28$ & Laboratory made \\
\hline
\end{tabular}

Table 2. Methods and accuracy of analysis

\begin{tabular}{c|c|c}
\hline & Accuracy $(\mathrm{l} \sigma)$ & Method of analysis (JIS) \\
\hline $\mathrm{Si}$ & $0.02 \%$ & Grarimetric method as Si dioxide \\
\hline $\mathrm{O}$ & $8 \mathrm{ppm}$ & Vacuum fusion method \\
\hline $\mathrm{Ni}$ & $0.06 \sim 0.08 \%$ & $\begin{array}{c}\text { EDTA titration after Ni dimethyl- } \\
\text { glyomine separation }\end{array}$ \\
\hline $\mathrm{Cr}$ & $0.06 \sim 0.10$ & $\begin{array}{c}\mathrm{K} \text { permanganate titration after } \\
\text { ammonium persulfate oxidation }\end{array}$ \\
\hline $\mathrm{Al}$ & 0.002 & Chromazurol-S absorption method \\
\hline
\end{tabular}

Table 3. Thermochemical data of interaction coefficients

\begin{tabular}{|c|c|c|c|c|c|}
\hline & $\mathrm{C}$ & $-\mathrm{Si}$ & $\mathrm{Ni}$ & $\mathrm{Cr}$ & $\mathrm{O}$ \\
\hline$e_{\mathrm{Si}}^{j}$ & $0.25^{7)}$ & $\begin{array}{l}(3910 / T \\
\quad-1.77)^{4)}\end{array}$ & $\left.0.007^{7}\right)$ & $0^{2)}$ & $-0.24^{4)}$ \\
\hline$e_{\mathrm{O}}^{j}$ & $-0.421^{4}$ & $-0.137^{4)}$ & $0.005^{3)}$ & $*$ & $\begin{array}{l}(-1750 / T \\
+0.76)^{4)}\end{array}$ \\
\hline
\end{tabular}

melt can be expressed by the following equations:

$$
\begin{aligned}
& \mathrm{SiO}_{2}(\mathrm{~S})=\underline{\mathrm{Si}}+2 \underline{\mathrm{O}} . \\
& \log K_{\mathrm{Si}}=a_{\mathrm{Si}_{1}} \cdot a_{\mathrm{O}}^{2} / a_{\mathrm{SiO}_{2}} .
\end{aligned}
$$

where, $a_{\mathrm{Si}}$ and $a_{0}$ : the Henrian activities of $\underline{\mathrm{Si}}$ and $\underline{\mathrm{O}}$, respectively in $\mathrm{wt} \%$

$a_{\mathrm{SiO}_{2}}$ : the activity with reference to solid silica.

$a_{\mathrm{Si}}$ and $a_{\mathrm{O}}$ are expressed by the following equations according to Wagner,

$$
\begin{aligned}
& a_{\mathrm{Si}}=f_{\mathrm{Si}}^{\mathrm{C}} \cdot f_{\mathrm{Si}}^{\mathrm{Si}} \cdot f_{\mathrm{Si}}^{\mathrm{Ni}} \cdot f_{\mathrm{Si}}^{\mathrm{Cr}} \cdot f_{\mathrm{Si}}^{\mathrm{o}} \cdot[\% \mathrm{Si}] \\
& a_{0}=f_{0}^{\mathrm{c}} \cdot f_{0}^{\mathrm{Si}} \cdot f_{0}^{\mathrm{Ni}} \cdot f_{0}^{\mathrm{Cr}} \cdot f_{0}^{\mathrm{o}} \cdot[\% \mathrm{O}]
\end{aligned}
$$

In Table 3, the interaction parameters used for the present study are summarized. Equation (2) may be rearranged as follows using the values in Table 3.

$$
\begin{aligned}
\log K_{\mathrm{Si}}= & \log a_{\mathrm{Si}} \cdot a_{\mathrm{O}}^{2} / a_{\mathrm{SiO}_{2}} \\
= & (3910 / T=2.044)[\% \mathrm{Si}]-0.602[\% \mathrm{C}] \\
& +0.015 \% \mathrm{Ni}-0.08 \% \mathrm{Cr} \\
& +(-3500 / T+1.28)[\% \mathrm{O}]+\log [\% \mathrm{Si}][\% \mathrm{O}]^{2}
\end{aligned}
$$

(here $e_{0}^{\mathrm{Cr}}=-0.040$ is used.)

In this equation, $K_{\mathrm{Si}}$ denotes the equilibrium con- 
stant of Eq. (1). Many researches have been made for the Fe-Si-O ternary system, and the 19th Committee of Japan Society for the Promotion of Science (JSPS) recommends the following equation. ${ }^{4}$

$$
\log K_{\mathrm{Si}}=-3.072 / T+11.76
$$

If Eqs. (3) and (4) hold for the stainless composition, $18 \mathrm{Cr}-8 \mathrm{Ni}, K_{\mathrm{Si}}$ value obtained by $\mathrm{Eq}$. (5) must agree with that from Eq. (6). Suzuki, Ban-ya and Fuwa $^{3)}$ report that Eqs. (3) and (4) is applicable to $10 \% \mathrm{Cr}$ and $5 \% \mathrm{Ni}$, while Chino, Nakamura, Tsunetomi and Segawa ${ }^{5}$ report that they hold up to $18 \% \mathrm{Cr}$ and $8 \% \mathrm{Ni}$.

Firstly in this experiment, the deoxidation equilibrium equation of $\mathrm{Si}$ for $18 \mathrm{Cr}-8 \mathrm{Ni}$ composition was measured using silica crucible and on this basis, $a_{\mathrm{SiO}_{2}}$ was investigated in equilibrium with the melt of this composition in various crucibles, such as lime, alumina, magnesia, etc., or in coexistence of slag of various basicity.

\section{Deoxidation Equilibrium in Silica Crucible}

First of all, the experiment to determine the deoxidation equilibrium equation of $\mathrm{Si}$ for $18 \mathrm{Cr}-8 \mathrm{Ni}$ melt was carried out using silica crucible without slag. $200 \mathrm{~g}$ of mother alloy and $0.3 \mathrm{~g} \mathrm{Fe}_{2} \mathrm{O}_{3}$ were melted in silica crucible, and after reaching designated temperatures $\left(1510^{\circ}, 1550^{\circ}, 1575^{\circ}\right.$ and $\left.1600^{\circ} \mathrm{C}\right)$, ferro-Si was added (Si: $0.2,0.4,0.6,0.8$ and $1.0 \%$ ). Although the equilibrium was reached in about $3 \mathrm{hr}$ after addition of ferro-Si as shown in Fig. 3, the melts were held $5 \mathrm{hr}$ for safety.

Figure 4 shows the values of $\log K_{\mathrm{Si}}$ given by Eq. (5) and $\log K_{\mathrm{si}}^{\prime}$ for $18 \mathrm{Cr}-8 \mathrm{Ni}$ melts. They are constant in the Si range of 0.3 to $1.6 \%$.

The relation between $\log K_{\mathrm{si}}$ and $1 / T$ is shown in Fig. 5. As the stainless steel melt has higher concentration of $\mathrm{Cr}, \log K_{\mathrm{Si}}$ greatly depends on the value of $\log f_{0}^{\mathrm{Cr}}$. So our calculation was made using the data of Kojima and Sano ${ }^{2}$ who measured the temperature dependency and the data of Suzuki, Ban-ya and Fuwa. ${ }^{3)}$

The $\log K_{\mathrm{Si}}$ obtained in this experiment was plotted against $1 / T$ which can be expressed by using the

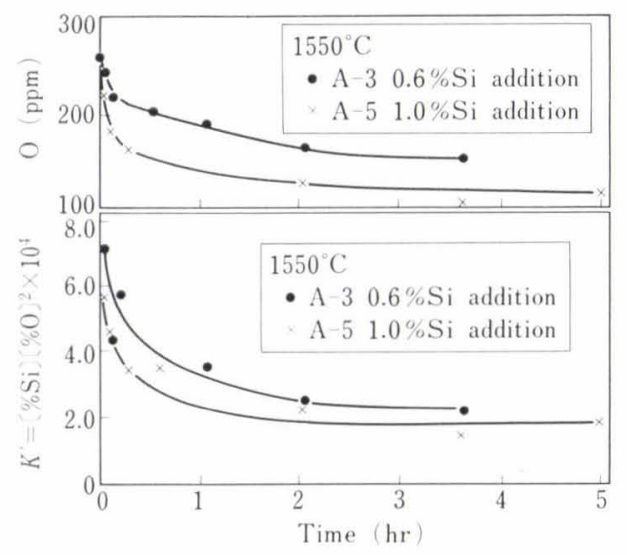

Fig. 3. Deoxidation curves with $\mathrm{Si}$ in silica crucibles for $18 \mathrm{Cr}-8 \mathrm{Ni}$ melts at $1550^{\circ} \mathrm{C}$ method of least squares as follows:

When

$$
\log f_{\mathrm{o}}^{\mathrm{Cr}}=(-369 / T+0.137)[\% \mathrm{Cr}]+0.0024[\% \mathrm{Cr}]^{1.75}
$$

(the data of Kojima and Sano) ${ }^{2)}$ is used,

$$
\begin{gathered}
\log K_{\mathrm{Si}}=-31740 / \mathcal{T}+12.347 \pm 0.0412 \\
r^{* *}=-0.9906
\end{gathered}
$$

and by use of $\log f_{\mathrm{O}}^{\mathrm{Cr}}=-0.040[\% \mathrm{Cr}]$ (the data of $\mathrm{Su}-$ zuki, Ban-ya and Fuwa), ${ }^{3)}$

$$
\begin{gathered}
\log K_{\mathrm{Si}}=-19690 / T+5.914 \pm 0.0412 \\
r^{* *}=-0.9724
\end{gathered}
$$

At $1600^{\circ} \mathrm{C}$, either of Eq. (7) or (8) gives the same value for $K_{\mathrm{si}}$, but at higher temperatures, greater becomes the difference between the values of equilibrium constant by Eqs. (7) and (8). The $\log K_{\mathrm{Si}}$ values thus obtained are compared with the results of other investigators in Fig. 6. When the value of $\log f_{0}^{\mathrm{Cr}}=$ $-0.040 \%$ Cr is used, $\log K_{\mathrm{Si}}$ agrees very well with the data of Suzuki, Ban-ya and Fuwa. ${ }^{3)}$ On the other hand, with $\log f_{0}^{\mathrm{Cr}}$ of Kojima and $\mathrm{Sano}^{2)}$ the value agrees with the JSPS recommended value. ${ }^{4}$

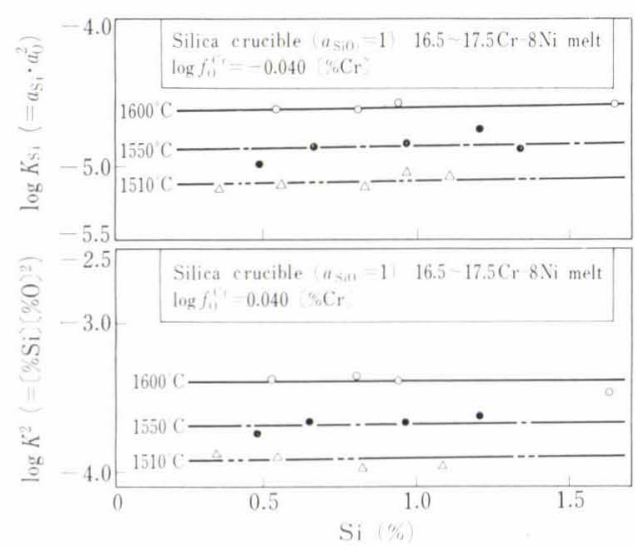

Fig. 4. The effect of Si content on the equilibrium constant, $K_{\mathrm{Si}}$ and the product, $K_{\mathrm{Si}}^{\prime}$ for $16.5 \sim 17.5 \mathrm{Cr}-8 \mathrm{Ni}$ melt with silica crucibles

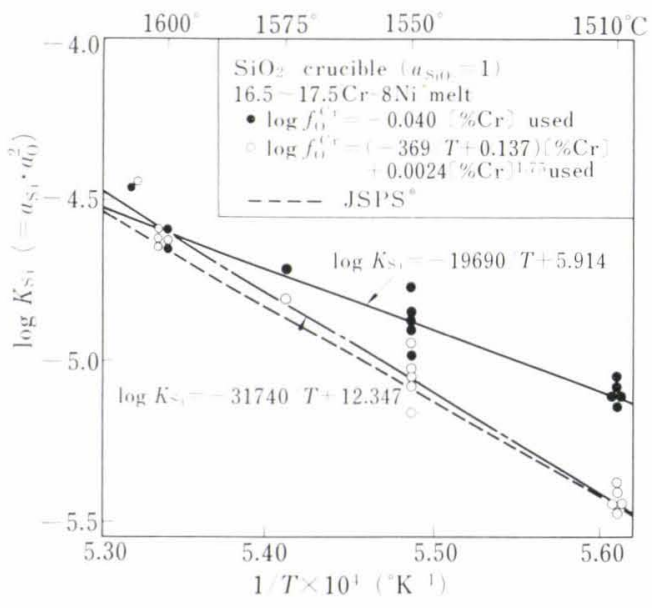

*Japan Society for the Promotion of Science

Fig. 5. Comparison of the results for $\log K_{\mathrm{Si}}\left(=a_{\mathrm{Si}} \cdot a_{\mathrm{O}}^{2}\right)$ calculated with various thermochemical data and Japan Society for the Promotion of Science's data 


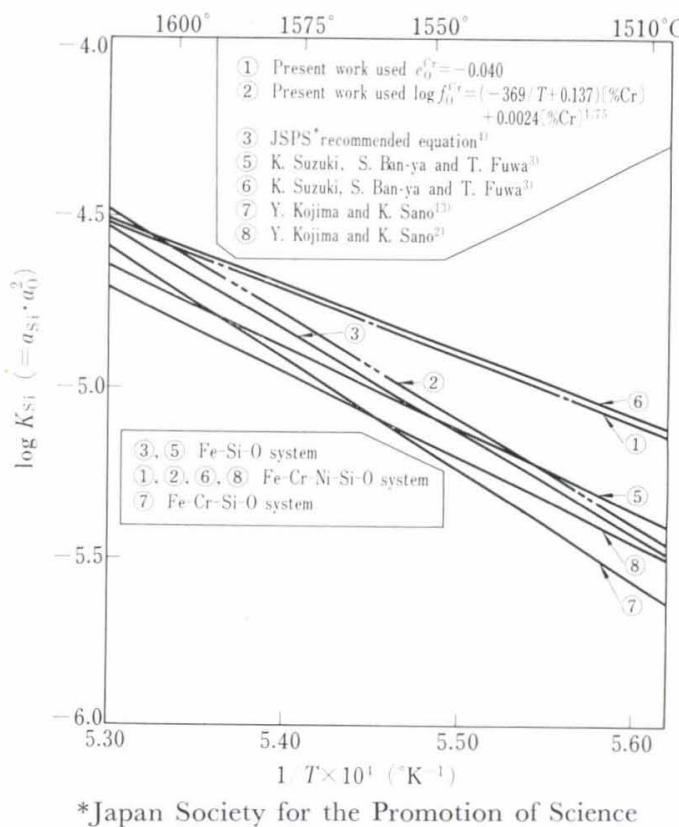

Fig. 6. The effect of temperature on the equilibrium constant, $K_{\mathrm{Si}}=a_{\mathrm{Si}} \cdot a_{\mathrm{o}}^{2}$

Since the stainless steel melt has higher Cr content than other alloying elements, $\log f_{0}^{\mathrm{Cr}}$ has greater influence on the equilibrium constant than other elements do. Therefore, many researches have been made for determining $e_{\mathrm{o}}^{\mathrm{Cr}}$. The values of $\log K_{\mathrm{Si}}$ of $18 \mathrm{Cr}-8 \mathrm{Ni}$ melt at $1600^{\circ} \mathrm{C}$ were calculated by using $e_{\mathrm{O}}^{\mathrm{Cr}}$ of various investigators. In Table 4, the calculated values of $\log K_{\mathrm{Si}}$ including the one obtained in this experiment are compared. It is noticeable that the all values almost agree at $1600^{\circ} \mathrm{C}$. Further $\log K_{\mathrm{Si}}$ obtained in our experiment agrees with the JSPS recommended value ${ }^{4)}$ at $1600^{\circ} \mathrm{C}$ within allowable error. Therefore, it can be mentioned with safety that the Wagner equation is applicable up to this composition.

Values of $\log f_{\mathrm{O}}^{\mathrm{Cr}}$ are almost consistent among the investigators at $1600^{\circ} \mathrm{C}$, but not at other temperatures. This is because $\log f_{\mathrm{O}}^{\mathrm{Cr}}$ has temperature dependency. For example, Chipman ${ }^{7}$ reports the temperature dependency at temperatures from $1550^{\circ}$ to $1650^{\circ} \mathrm{C}$ for high chromium concentration (25 to $40 \%$ ). Chino, Nakamura, Tsunetomi and Sagawa ${ }^{8)}$ reported $e_{0}^{\mathrm{Cr}}$ having temperature dependency, i.e., -0.047 (at $1600^{\circ} \mathrm{C}$ ), -0.043 (at $1700^{\circ} \mathrm{C}$ ) and -0.038 (at $1800^{\circ} \mathrm{C}$ ) with $e_{0}^{\mathrm{Cr}}$. The $\log K_{\mathrm{Si}}$ of present work agrees well with the JSPS recommended value when Kojima and Sano's temperature dependency for $\log f_{0}^{\mathrm{cr}}$ is used. However, it is hardly possible to judge what of these values is the most appropriate.

Since in the stainless steel refining, the temperature of bath after $\mathrm{O}$ blowing sometimes exceeds $2000^{\circ} \mathrm{C}$, the melt is refined in the temperature range of $1500^{\circ}$ to $2000^{\circ} \mathrm{C}$. Accurate data of $\log f_{0}^{\mathrm{Cr}}$ for the entire temperature range are desirable.

\section{The Influence of Crucible Materials on the Deoxidation Equilibrium}

The effect of crucible materials on the deoxidation
Table 4. Comparison of $\log K_{\mathrm{Si}}$ at $1600^{\circ} \mathrm{C}$

\begin{tabular}{|c|c|c|c|}
\hline Researcher & $\epsilon_{\mathrm{O}}^{\mathrm{Cr}}$ or $\log f_{\mathrm{O}}^{\mathrm{Cr}}$ used & $\log K_{\mathrm{Si}}$ & Composition \\
\hline \multirow{2}{*}{$\begin{array}{l}\text { Present } \\
\text { work }\end{array}$} & $e_{0}^{\mathrm{Cr}}=-0.040^{5)}$ & $\begin{array}{l}-4.627_{2} \\
\pm 0.014_{8}\end{array}$ & \multirow{2}{*}{$(17 \widetilde{17} .5 \mathrm{Cr}-8 \mathrm{Ni}$} \\
\hline & $\begin{array}{r}\log f_{\mathrm{O}}^{\mathrm{Cr}} \text { of Sano, } \\
\text { et al. }\end{array}$ & $\begin{array}{l}-4.625_{3} \\
\pm 0.014_{8}\end{array}$ & \\
\hline $\begin{array}{l}\text { Chino, } \\
\text { et al. }{ }^{5)}\end{array}$ & $e_{0}^{\mathrm{Cr}}=-0.039^{6)}$ & $\begin{array}{l}-4.64 \\
\quad \pm 0.02\end{array}$ & $18 \mathrm{Cr}-8 \mathrm{Ni}$ \\
\hline $\begin{array}{l}\text { Kojima, } \\
\quad \text { et al. }{ }^{2)}\end{array}$ & $\begin{array}{r}\log f_{0}^{\mathrm{Cr}} \text { of Sano, } \\
\text { et al. }\end{array}$ & $-4.80_{6}^{4) *}$ & $18 \mathrm{Cr}-9 \mathrm{Ni}$ \\
\hline $\begin{array}{l}\text { Suzuki, } \\
\quad \text { et } \text { al. }^{3)}\end{array}$ & $e_{0}^{\mathrm{Cr}}=-0.040$ & $-4.55^{* *}$ & $17 \mathrm{Cr}-8 \mathrm{Ni}$ \\
\hline $\begin{array}{l}\text { JSPS } \\
\quad \text { value }{ }^{4)}\end{array}$ & - & -4.64 & $\mathrm{Fe}-\mathrm{Si}-\mathrm{O}$ system \\
\hline
\end{tabular}

* Calculated from the equation $\log K_{\mathrm{Si}}=-25400 / T+8.757$, which is obtained from Table 4 in Ref. 2) by the method of least squares.

** Plot of Fig. 10, Ref. 3)

Table 5. Influence of crucible materials on activity of silica at $1600^{\circ} \mathrm{C}$ for $\mathrm{Fe}-\mathrm{Si}-\mathrm{O}$ melts

\begin{tabular}{ll|l}
\multicolumn{1}{c}{ Researcher } & Crucible material & \multicolumn{1}{|c}{$a_{\mathrm{SiO}_{2}}$} \\
\hline Suzuki, Ban-ya and Fuwa $^{3)}$ & $\mathrm{Al}_{2} \mathrm{O}_{3}$ & 0.31 \\
& $\mathrm{MgO}$ & 0.07 \\
Yokoyama and $\mathrm{Oi}^{97}$ & $\mathrm{CaO}$ & $0.25, \quad 0.16_{7}$ \\
Kawawa and Okubo & & 0.29 \\
& $\mathrm{Al}_{2} \mathrm{O}_{3}$ & 0.29 \\
& $\mathrm{C} 2 \mathrm{O}-\mathrm{CaF}_{2}(20 \%)$ & 0.015
\end{tabular}

by $\mathrm{Si}$ is known for the $\mathrm{Fe}-\mathrm{Si}-\mathrm{O}$ ternary system, an example of which is shown in Table 5. In our experiment, the effect of crucible materials was demonstrated with $18 \mathrm{Cr}-8 \mathrm{Ni}$ composition melt. Crucible materials are the following: lime-silica (80/20), limefluorspar (10 to $15 \%$ fluorspar), zirconia, alumina and magnesia.

The experimental method was the same as that for silica crucible. The holding time was 5 to $6 \mathrm{hr}$ since the constant oxygen concentration was attained in 4 to $4.5 \mathrm{hr}$ after $\mathrm{Si}$ addition. The deoxidation equilibrium run was carried out at temperatures of $1510^{\circ}$, $1550^{\circ}$ and $1600^{\circ} \mathrm{C}$, and the activity of silica was obtained from the following equation.

$$
\log a_{\mathrm{SiO}_{2}}=\log a_{\mathrm{Si}} \cdot a_{\mathrm{o}}^{2}-\log K_{\mathrm{Si}}
$$

Here, $\log \kappa_{\mathrm{Si}}$ given by Eq. (8) was used.

The experimental results in this series are summarized in Table 6. As noted therein, $a_{\mathrm{SiO}_{2}}$ is the lowest with lime and lime containing crucibles, while it is the highest with alumina crucible. Magnesia and zirconia stay in the middle.

From these results, it is noted that the deoxidation ability of $\mathrm{Si}$ is greatly influenced by crucible materials. This phenomenon is generally explained by that silica formed on deoxidation reaches the crucible wall and is absorbed thereinto which causes the reduction in activity of silica, eventually increasing the deoxidation capability of Si. The difference in the deoxidation capability of $\mathrm{Si}$ for various crucible materials 
Table 6. Activities of silica for various crucibles

\begin{tabular}{|c|c|c|c|}
\hline \multirow{2}{*}{ Crucible materials } & \multicolumn{3}{|c|}{$a_{\mathrm{SiO}_{2}}(\% \mathrm{Si}$ in melt $)$} \\
\hline & $1600^{\circ} \mathrm{C}$ & $1550^{\circ} \mathrm{C}$ & $1510^{\circ} \mathrm{C}$ \\
\hline \multirow{2}{*}{$\mathrm{CaO}$} & $0.002_{0}(0.42)$ & $0.005_{5}(0.63)$ & $0.008_{6}(0.26)$ \\
\hline & $0.004_{0}(0.55)$ & & $0.007_{5}(0.77)$ \\
\hline \multirow{3}{*}{$\begin{array}{c}\mathrm{CaO}-\mathrm{SiO}_{2} \\
\mathrm{CaO} / \mathrm{SiO}_{2}=80 / 20\end{array}$} & $0.005_{5}(0.23)$ & $0.003_{6}(0.20)$ & $0.008_{0}(0.36)$ \\
\hline & $0.008_{5}(0.23)$ & $0.022_{4}(0.47)$ & \\
\hline & & $0.016_{1}(0.69)$ & \\
\hline \multirow{3}{*}{$\begin{array}{c}\mathrm{CaO}-\mathrm{CaF}_{2} \\
\left(85 \mathrm{CaO}-10 \mathrm{CaF}_{2}\right)\end{array}$} & & $0.007_{2}(0.14)$ & \\
\hline & & $0.010_{9}(0.36)$ & \\
\hline & & $0.019_{8}(0.37)$ & \\
\hline $\begin{array}{c}\mathrm{CaO}-\mathrm{CaF}_{2} \\
\left(77 \mathrm{CaO}-15 \mathrm{CaF}_{2}\right)\end{array}$ & & $0.027_{7}(0.60)$ & \\
\hline \multirow{4}{*}{$\mathrm{Al}_{2} \mathrm{O}_{3}$} & $0.12_{4} \quad(0.42)$ & $0.24_{1} \quad(0.42)$ & $0.25_{0} \quad(0.49)$ \\
\hline & $0.41_{6} \quad(1.26)$ & $0.24_{1} \quad(0.51)$ & $0.51_{4} \quad(1.40)$ \\
\hline & & $0.55_{7} \quad(1.05)$ & \\
\hline & & $0.20_{4} \quad(1.29)$ & \\
\hline \multirow{2}{*}{$\mathrm{MgO}$} & $0.027_{8}(0.38)$ & $0.022_{2}(0.37)$ & $0.085_{8}(0.33)$ \\
\hline & $0.17_{5} \quad(1.02)$ & $0.038_{2}(0.41)$ & $0.11_{4} \quad(0.92)$ \\
\hline \multirow[t]{2}{*}{$\mathrm{ZrO}_{2}$} & $0.051_{2}(1.03)$ & $0.041_{6}(0.43)$ & $0.033_{5}(0.54)$ \\
\hline & & $0.088_{6}(1.09)$ & \\
\hline
\end{tabular}

shown in Table 6 could be interpreted by this concept.

As noted in Table 6, even with the same crucible material, $a_{\mathrm{SiO}_{2}}$ depends on temperature and silicon concentration of melt. The lower is temperature, the greater becomes $a_{\mathrm{SiO}_{2}}$, and the higher is the concentration of $\mathrm{Si}$, the greater becomes $a_{\mathrm{SiO}_{2}}$ as seen in Fig. 7. This is explained by that at lower temperatures, more silica precipitate remain in metal due to its slow reaction with the crucible material.

\section{The Influence of Slag Composition on Deoxidation Equi- librium}

To make clear the influence of slag compositions on deoxidation equilibrium of the stainless steel melt, firstly the $50 \% \mathrm{CaO}-50 \% \mathrm{SiO}_{2}$ slag was chosen for the preliminary experiment. This slag was fused together with the mother alloy in a zirconia crucible and a magnesia crucible. However, this experiment failed as both crucibles were attacked by the slag and did not hold even for $1 \mathrm{hr}$. Then replacing this slag with the $\mathrm{CaO}-\mathrm{SiO}_{2}-\mathrm{Al}_{2} \mathrm{O}_{3}$ ternary system $\left(\mathrm{Al}_{2} \mathrm{O}_{3}\right.$ saturated), and using an alumina crucible, the deoxidation power of $\mathrm{Si}$ was examined in the existence of slags with different $\mathrm{CaO} / \mathrm{SiO}_{2}$ ratio. The synthetic slag was made from commercial grade $\mathrm{CaCO}_{3}, \mathrm{Al}_{2} \mathrm{O}_{3}$ and $\mathrm{SiO}_{2}$ reagents using a graphite crucible.

The experiment procedure is as follows: $75 \mathrm{~g}$ of the synthetic slag, $200 \mathrm{~g}$ of mother alloy and $0.3 \mathrm{~g}$ of $\mathrm{Fe}_{2} \mathrm{O}_{3}$ were inserted in an alumina crucible and melted in Ar atmosphere and after being held for 5 to $10 \mathrm{~min}$ at $1600^{\circ} \mathrm{C}$, ferro-Si was added and then the melt was stirred for about $30 \mathrm{sec}$ with a quartz rod. The viscosity of slag was extremely great at

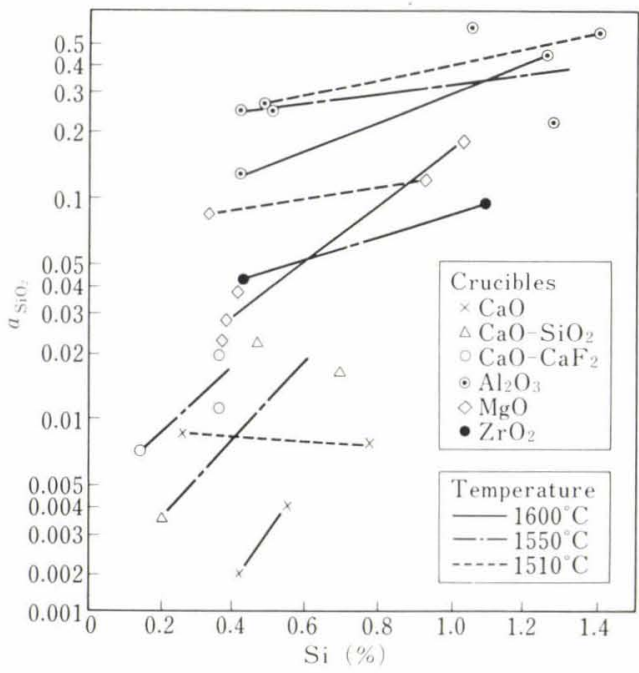

Fig. 7. Influence of Si content in the liquid stainless steel on the activity of silica for various crucibles

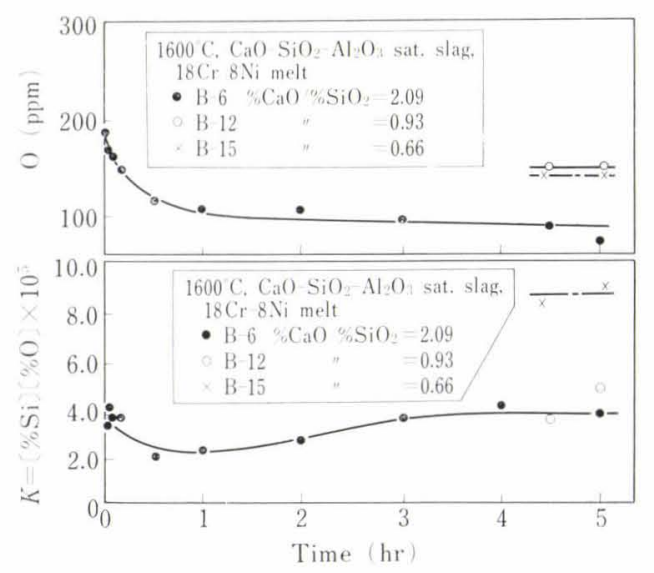

Fig. 8. Deoxidation curves with $\mathrm{Si}$ in alumina crucible covered with $\mathrm{CaO}-\mathrm{SiO}_{2}-\mathrm{Al}_{2} \mathrm{O}_{3}$ (sat.) slag at $1600^{\circ} \mathrm{C}$

this time, and the quartz rod did not disolve into slag. To determine the equilibration time, the change in oxygen concentration with time was measured for two types of slag, which showed $\mathrm{O}$ value becoming constant in about $3 \mathrm{hr}$, indicating that the equilibrium is presumably established by this time. According to this information, the experiments thereafter were carried out with the holding time of $5 \mathrm{hr}$. Ferro-Si was added to each slag at three $\underline{\mathrm{Si}}$ levels of $0.2,0.5$ and $0.8 \%$ to approach the equilibrium from another direction. The results of these experiments are shown in Fig. 8. The $a_{\mathrm{SiO}_{2}}$ values calculated by Eq. (9) and standard deviations for each composition of slags are shown in Table 7 . The $\log K_{\mathrm{Si}}$ value from Eq. (8) is used in this calculation.

In this consideration, the influence of small amount of $\mathrm{FeO}$ and $\mathrm{Cr}_{2} \mathrm{O}_{3}$ on $a_{\mathrm{SiO}_{2}}$ has been ignored.

Figure 9 shows the relation between $a_{\mathrm{SiO}_{2}}$ and $\% \mathrm{CaO} / \% \mathrm{SiO}_{2}, a_{\mathrm{SiO}_{2}}$ decreases with increasing $\% \mathrm{Ca}$ $\mathrm{O} / \% \mathrm{SiO}_{2}$ and levels off beyond $\% \mathrm{Cal} / \% \mathrm{SiO}_{2}=3.0$. Any further increase in basicity is not considered to increase the deoxidation ability of $\mathrm{Si}$ and the limit of $a_{\mathrm{SiO}_{2}}$ with the slag of this series appears to be around 
Table 7. Activities of silica for various composition of $\mathrm{CaO}$ $-\mathrm{SiO}_{2}-\mathrm{Al}_{2} \mathrm{O}_{3}$ slag at $1600^{\circ} \mathrm{C}$

\begin{tabular}{c|c|c|c|c|c|}
\hline Heat No. & $V=\frac{\% \mathrm{CaO}}{\% \mathrm{SiO}_{2}}$ & $\begin{array}{c}\% \mathrm{SiO}_{2} \text { as } \\
\mathrm{presumed} \\
\% \mathrm{CaO}+\end{array}$ & \multicolumn{2}{|c|}{$a_{\mathrm{SiO}_{2}}$} & $n$ \\
\hline B-3 & 3.54 & $22.02 \%$ & $0.038_{6}$ & & 1 \\
\hline B-4, B-6 & 2.09 & 32.32 & $0.057_{9}$ & $0.009_{5}$ & 3 \\
B-7, B-9 & 1.37 & 42.25 & $0.118_{5}$ & $0.019_{0}$ & 3 \\
B-11, 12 & 0.93 & 51.70 & $0.180_{6}$ & $0.020_{4}$ & 2 \\
B-13, B-15 & 0.66 & 60.15 & $0.199_{0}$ & $0.024_{0}$ & 3 \\
B-16, B-18 & 0.38 & 72.33 & $0.487_{3}$ & $0.058_{6}$ & 3 \\
\hline
\end{tabular}

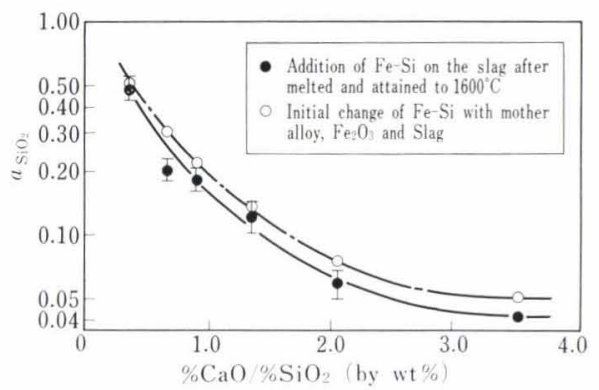

Fig. 9. The effect of the basicity of $\mathrm{CaO}-\mathrm{SiO}_{2}-\mathrm{Al}_{2} \mathrm{O}_{3}$ (sat.) slag equilibriated with liquid stainless steel on the activity of silica

\subsection{3 to 0.04 .}

The above-mentioned experiment was conducted by such procedures that the mother alloy, slag and $\mathrm{Fe}_{2} \mathrm{O}_{3}$ were mixed together and melted, and, upon reaching $1600^{\circ} \mathrm{C}$, ferro-Si was added to the top of the slag. The equilibrium condition was approached using oxygen saturated melt. As the next step, ferroSi was initially charged with the mother alloy, slag and $\mathrm{Fe}_{2} \mathrm{O}_{3}$. The results are shown in Fig. 9 together with the results of the previous work. As noted in this figure, the data show somewhat higher $a_{\mathrm{SiO}_{2}}$ value, but it still remains within the standard deviation, indicating its fairly good agreement with the previous works.

The relation between $a_{\mathrm{SiO}_{2}}$ values in $\mathrm{CaO}-\mathrm{SiO}_{2}-$ $\mathrm{Al}_{2} \mathrm{O}_{3}$ ternary system and those obtained from $\mathrm{Fe}-\mathrm{Cr}-$ $\mathrm{Si}-\mathrm{O}$ equilibrium is considered as follows. As to the $a_{\mathrm{SiO}_{2}}$ in this slag system, Sambongi and Omori ${ }^{11)}$ determined $a_{\mathrm{SiO}_{2}}$ from the measurement of electromotive force for a double cell and Chipman ${ }^{12)}$ from the distribution equilibrium of $\mathrm{Si}$ between slag and carbon saturated iron. Both values do not agree for the $\mathrm{Al}_{2} \mathrm{O}_{3}$ saturated composition range in which the present work was conducted. Figure 10 shows iso-activity lines of silica by Sambongi and Omori11) together with our results obtained from Eq. (9) in the stainless steel melts. In this figure, it can be seen that the $a_{\mathrm{SiO}_{2}}$ values of present work are higher than those of Sambongi and Omori ${ }^{11)}$ as $\left(\% \mathrm{SiO}_{2}\right)$ increases. When compared with Chipman's values, even more discrepancy is observed.

Though the purpose of this study is not to determine $a_{\mathrm{SiO}_{2}}$, this phenomenon is interesting to evaluate the role of slag in silicon deoxidation.

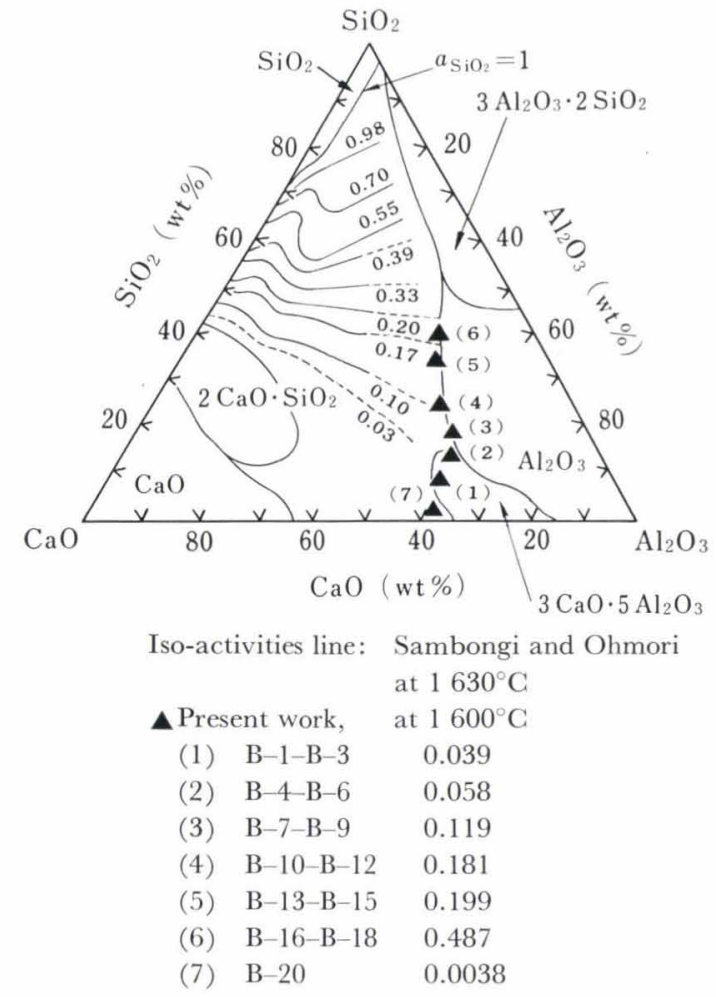

Fig. 10. $\mathrm{SiO}_{2}$ activities on the system $\mathrm{CaO}-\mathrm{SiO}_{2}-\mathrm{Al}_{2} \mathrm{O}_{3}$

Kojima and $\mathrm{Sano}^{13)}$ have investigated the $\mathrm{Fe}-\mathrm{Cr}$ $\mathrm{Si}-\mathrm{O}$ equilibrium under acidic slag, $a$, in silica crucible. Their $\log K_{\mathrm{Si}}$ agrees with that for $\mathrm{Fe}-\mathrm{Si}-\mathrm{O}$ system in which $a_{\mathrm{SiO}_{2}}$ is defined as unity. Hilty, Rassbach and Crafts $^{14)}$ also investigated the equilibrium between $\mathrm{Si}$ and $\mathrm{Cr}$ in $\mathrm{Fe}-\mathrm{Cr}$ melt using a silica crucible. Though they did not discuss the relation between $\mathrm{O}$ content and slag composition, the oxygen concentration is presumably controlled by Eq. (1). According to the authors' calculation, using their data for $\mathrm{Si}-\mathrm{Cr}$ equilibrium and the oxygen solubility of $\mathrm{Fe}-\mathrm{Cr}$ melt, ${ }^{15)}$ the oxygen concentration in the melt with $17 \% \mathrm{Cr}$ in equilibrium with chromium oxide containing slag saturated with silica is approximately $300 \mathrm{ppm}$. This value roughly agrees with that given by Eq. (1).

This means that the equilibrium defined by $a_{\mathrm{SiO}_{2}}$ in slag was not established in this work. The phenomenon can be explained that the deoxidation reaction between the melt and slag might be so sluggish after the oxygen concentration in the melt drops to a certain constant level that the equilibrium given by Eq. (1) on the basis of the activity in slag is hardly attainable.

From these considerations, Eq. (1) might be applied to define the equilibrium of the melt with basic slag as a function of silica activity. In our study, however, the $a_{\mathrm{SiO}_{2}}$ values calculated from $\mathrm{Si}-\mathrm{O}$ equilibrium did not agree with that in the coexisting slag. This means that the equilibrium was not established in this work.

Usage of an $\mathrm{Al}_{2} \mathrm{O}_{3}$ crucible in the present work may be a main reason why the equilibrium state was not attained. As made clear previously, the Si-O equili- 


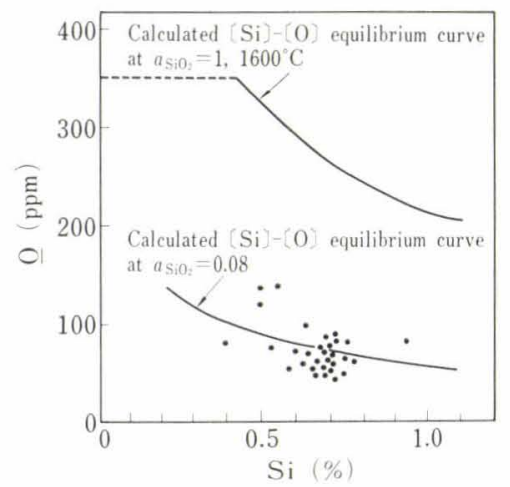

Fig. 11. Relation between $\mathrm{O}$ and $\mathrm{Si}$ content of $18 \mathrm{Cr}-8 \mathrm{Ni}$ melt in ladle $(10 \mathrm{t}$ basic arc furnace Slag composition: $\mathrm{CaO} 40 \sim 50 \%, \mathrm{SiO}_{2} 20 \%$ )

brium is greatly influenced by crucible materials. For instance, the precipitation of chromium oxide at refractory wall may make it impossible kinetically to attain the equilibrium state which is determined by $a_{\mathrm{SiO}_{2}}$ in coexisting slag.

It is concluded, however, that slag coexisting with melt has great influence on the deoxidation power of $\mathrm{Si}$ and the basic slag improves the deoxidation power of Si.

Figure 11 shows the relation between $\mathrm{Si}$ and $\mathrm{O}$ contents in $18 \mathrm{Cr}-8 \mathrm{Ni}$ melts on tapped from a $10 \mathrm{t}$ basic electric furnace lined by $\mathrm{MgO}$. In this figure, the equilibrium lines of $\mathrm{Fe}-\mathrm{Cr}-\mathrm{Si}-\mathrm{O}$ of $a_{\mathrm{SiO}_{2}}=1$ and $a_{\mathrm{SiO}_{2}}=0.08$ at $1600^{\circ} \mathrm{C}$ are shown together with the observed oxygen values. To this case, ( $\% \mathrm{CaO}) /$ $\left(\% \mathrm{SiO}_{2}\right)$ is greater than 2 , and $a_{\mathrm{SiO}_{2}}$ of slag is less than 0.02 .

Thereby it is easily understood that in the actual operation the deoxidation power is greatly improved by basic slag and that the mixing of slag and melt is favorable for reducing the oxygen concentration in silicon deoxidation practice.

\section{Conclusion}

The authors measured the deoxidation equilibrium of $\mathrm{Si}$ for $18 \mathrm{Cr}-8 \mathrm{Ni}$ melt using a silica crucible, including the experiments to examine the influence of crucible materials and that of $\mathrm{CaO}-\mathrm{SiO}_{2}-\mathrm{Al}_{2} \mathrm{O}_{3}$ ternary slag on the deoxidation equilibrium of $\mathrm{Si}$ and have obtained the following results:

(1) The deoxidation equilibrium of $\mathrm{Si}$ in the stainless steel melt can be expressed by the following experimental equations:

$$
\log K_{\mathrm{si}}=31740 / T+12.347 \pm 0.041
$$

Herein,

$$
\begin{array}{r}
\log f_{\mathrm{o}}^{\mathrm{cr}}=(-369 / T+0.137)[\% \mathrm{Cr}]+0.0024[\% \mathrm{Cr}]^{1.75} \\
\log K_{\mathrm{Si}}=-19690 / T+5.914 \pm 0.041 \ldots \ldots \ldots(\mathrm{l})
\end{array}
$$

Herein,

$$
\log f_{0}^{\mathrm{cr}}=-0.040[\% \mathrm{Cr}]
$$

At $1600^{\circ} \mathrm{C}$, both of Eqs. (a) and (b) give completely the same value for $\log K_{\mathrm{Si}}$, which also agrees with the value recommended by the Japan Society for the Promotion of Science for the $\mathrm{Fe}-\mathrm{Si}-\mathrm{O}$ ternary system within allowable error of the experiment. Therefore, Eqs. (c) and (d) are considered to be applicable up to the stainless steel composition.

$$
\begin{aligned}
& a_{\mathrm{Si}}=f_{\mathrm{Si}}^{\mathrm{Cr}} \cdot f_{\mathrm{Si}}^{\mathrm{Si}} \cdot f_{\mathrm{Si}}^{\mathrm{Ni}} \cdot f_{\mathrm{Si}}^{\mathrm{Cr}} \cdot f_{\mathrm{Si}}^{\mathrm{O}}[\% \mathrm{Si}] \\
& a_{\mathrm{O}}=f_{\mathrm{O}}^{\mathrm{C}} \cdot f_{\mathrm{O}}^{\mathrm{Si}} \cdot f_{\mathrm{O}}^{\mathrm{Ni}} \cdot f_{\mathrm{O}}^{\mathrm{Cr}} \cdot f_{\mathrm{O}}^{\mathrm{O}}[\% \mathrm{O}] .
\end{aligned}
$$

(2) The deoxidation ability of Si was studied using various crucible materials including lime, lime-silica, lime-magnesia, zirconia, etc. Lime and lime-containing crucibles reduce $a_{\mathrm{SiO}_{2}}$ mostly, while the effect of alumina crucible is comparatively small. Magnesia and zirconia crucibles affect intermediately. The influence of crucibles of the same material on deoxidation depends on temperature and the amount of Si added. This can be considered that the equilibrium state was not established even when 5 to $7 \mathrm{hr}$ of equilibrium time was given.

(3) The deoxidation equilibrium of $\mathrm{Si}$ under $\mathrm{CaO}-\mathrm{SiO}_{2}-\mathrm{Al}_{2} \mathrm{O}_{3}$ (Sat.) slag was measured using an $\mathrm{Al}_{2} \mathrm{O}_{3}$ crucible at $1600^{\circ} \mathrm{C}$, and $a_{\mathrm{SiO}_{2}}$ was determined. From this result, it was found that $\mathrm{O}$ by silicon deoxidation is greatly influenced by basicity of coexisting slag and that the observed $a_{\mathrm{SiO}_{2}}$ was larger than the estimation from the slag composition.

(4) From the above-mentioned results, it is concluded that the deoxidation power of $\mathrm{Si}$ in actual stainless steel melt is enhanced by using basic slag. However, it seems to be difficult to attain the equilibrium oxygen content expected from the slag composition.

\section{Acknowledgements}

The authors wish to express many thanks to Dr. D. C. Hilty of Ferroalloy Division, Union Carbide Corporation and Dr. H. Sakao, Professor of Nagoya University for their fruitful discussions given to this work.

\section{REFERENCES}

1) R. A. Waish, S. Ramachandran and J. C. Fulton: Trans. Met. Soc. AIME, 227 (1963), 1380.

2) Y. Kojima and K. Sano: Tetsu-to-Hagané, 50 (1964), 888.

3) K. Suzuki, S. Ban-ya and T. Fuwa: Tetsu-to-Hagané, 56 (1970), 20.

4) The 19th Committee of Japan Society for the Promotion of Science: "Recommended Equilibrium Values in Steel Making Reaction", Nikkan Kogyo Shimbun, Tokyo, (1968), 39.

5) H. Chino, Y. Nakamura, E. Tsunetomi and K. Segawa: Proc. 19th Committee of Japan Society for Promotion of Science, (1968), 8376.

6) H. Sakao and K. Sano: J. JIM, 23 (1959), 671.

7) J. Chipman: JISI, 180 (1955), 97.

8) Proc. International Conference on The Science and Technology of Iron and Steel, ISIJ, Tokyo, (1971), 456.

9) E. Yokoyama and H. Ohi: Tetsu-to-Hagané, 55 (1969), 454.

10) T. Kawawa and M. Okubo: Tetsu-to-Hagané, 53 (1967), 1569.

11) K. Sambongi and Y. Omori: J. JIM, 21 (1957), 296.

12) J. Chipman: "Physical Chemistry of Process Metallurgy" 
(Part I), Interscience Publishers, Inc., New York, (1961), 27.

13) Y. Kojima and K. Sano: Tetsu-to-Hagané, 50 (1964), 22.

14) D. C. Hilty, H. P. Rassbach and W. Crafts: J. ISI, 180 (1955), 116

15) D. C. Hilty, W. D. Forgeng and R. L. Forlman: Trans. Met. Soc. AIME, 203 (1955), 253.

\section{Discussions}

D. C. Hilty (Ferroalloy Division, Union Carbide Corporation)

(1) During my investigations of oxygen solubility and oxide phase relations in the $\mathrm{Fe}-\mathrm{Cr}-\mathrm{O}$ system, I made some experiments in $\mathrm{SiO}_{2}$ crucibles so that the system was saturated with both chromium oxides and $\mathrm{SiO}_{2}$. If you consider my data in conjunction with the chromium oxide phases that were established in my $\mathrm{Fe}-\mathrm{Cr}-\mathrm{O}$ paper, you can see that $\mathrm{Cr}$ and $\mathrm{Si}$ interact rather strongly; i.e., Cr seems to have a strong effect on the activity of Si. At one time, John Chipman and I planned to use these data to derive the activity coefficients for $\mathrm{Si}$ and $\mathrm{Cr}$, but we never got around to doing it.

(2) I am not surprised that your results for $a_{\mathrm{SiO}}$ were higher than those you calculated from slag composition. In fact, I suspected that this would be the case, which is why I suggested checking the experimental melts for actual concentrations of $\mathrm{Ca}$ and $\mathrm{Al}$.

Our own investigations have led us to the conclusion that in experimental work of this kind, once one goes beyond a simple ternary system of $\mathrm{Fe}, \mathrm{O}$ and a deoxidizer, the metal does not necessarily come into equilibrium with the refractories and/or slag unless you happen to hit the exact slag or refractory composition required for true equilibrium according to the phase rule.

I have found it more advantageous to determine the equilibrium oxide phase by analyzing (metallographically, X-ray and the microprobe) the inclusions precipitated in the melt when it freezes. These inclusions are the true equilibrium phase and may bear only an artificial or indirect relation to any slag unless the slag is permitted to form from the melt.

$\mathrm{Ca}$ will lower the $a_{\mathrm{SiO}_{2}}$, but the amount of lowering is a function of the amount of Ca or $a_{\mathrm{Ca}}$ dissolved in the metal. This can be quite different from what one would calculate from the basicity of a slag which is made up outside of the metal and then brought in contact with it.

One way of estimating the composition of the oxide phase is to run microprobe analysis on the surface of the crucible that was in contact with the metal. Usually, a film of the equilibrium oxide will precipitate on the surface of the crucible. Analysis of the inclusions, however, is the best way. This is something that has not been fully understood by many investigators, including Chipman, who were accustomed to thinking in terms of simple ternary deoxidation systems. Ramachandran, however, learned this from us and tried to apply it.
Incidentally, it was through study of the precipitated oxide inclusions that we discovered that the oxide phase in equilibrium with $\mathrm{O}$-saturated high- $\mathrm{Cr}$ FeCr alloys is $\mathrm{Cr}_{3} \mathrm{O}_{4}$ containing up to about $10 \% \mathrm{Fe}$ not $\mathrm{Cr}_{2} \mathrm{O}_{3}$ as had been previously always assumed.

As a further matter of interest, we always find the presence of $\mathrm{Ca}$ (and frequently $\mathrm{Mg}$ ) by microprobe analysis of inclusions in stainless steel heats made by standard 2-slag practice in the arc furnace. The strong reducing conditions present under the second slag is sufficient to introduce a little $\mathrm{Ca}$ and/or $\mathrm{Mg}$ into the metal. This, in turn, slightly lowers $a_{\mathrm{SiO}_{2}}$ in equilibrium with the metal.

\section{The Authors}

It is clear that you are pointing out the following concerning our study

(1) Because of the strong interaction between $\mathrm{Si}$ and $\mathrm{Cr}$, $\mathrm{Si}$ is not much of a deoxidizer for stainless steel in the amounts normally employed.

(2) This has been identified in your studies on the oxygen solubility in $\mathrm{Fe}-\mathrm{Cr}-\mathrm{O}$ and $\mathrm{Fe}-\mathrm{Cr}-\mathrm{Si}-\mathrm{O}$ (in silica crucible, saturated with silica and chromium oxide slag) systems

(3) You suggested that we examine the melts for evidence of Ca pick up. In order to improve deoxidation of stainless steel by lowering $a_{\mathrm{SiO}_{2}}$, it is necessary that the element responsible for the activity lowering (by precipitating the impure silica) should also be dissolved in the steel.

As to the value of $e_{\mathrm{si}}^{\mathrm{Cr}}$. I have calculated the value of $\log K_{\mathrm{Si}}$ in $\mathrm{Fe}-\mathrm{Cr}-\mathrm{Si}-\mathrm{O}$ equilibrium of $18-8$ melt from our experimental values and other works (Dr. Fuwa and Dr. Sano's studies on the deoxidation by Si in high alloy steel melt). In my study, I used the value of $f_{\mathrm{Si}}^{\mathrm{Cr}}=1$. (Dr. Fuwa ${ }^{3)}$ and Dr. Sano ${ }^{2)}$ used the values of $\log f_{\mathrm{Si}}^{\mathrm{Cr}}=0, \log f_{\mathrm{Si}}^{\mathrm{Cr}}=-0.003[\% \mathrm{Cr}]$, respectively.) The values of $\log K_{\mathrm{Si}}$ calculated from the results in $\mathrm{Fe}-\mathrm{Cr}-\mathrm{Si}-\mathrm{O}$ system were well accorded to the authorized value in $\mathrm{Fe}-\mathrm{Si}-\mathrm{O}$ system. It means that it is not wrong to regard the value of $f_{\mathrm{Si}}^{\mathrm{Cr}}$ as unity and that the interaction between $\mathrm{Si}$ and $\mathrm{Cr}$ is negligible.

I agree with you that $\mathrm{O}$ in the stainless steel melt should be equilibrium with $a_{\mathrm{SiO}_{2}}$ given by the impure silica precipitated from the melt. Through my study, the oxygen concentration might coincide with the one determined from the composition of the precipitated inclusion. In this concept, I do not conclude that the equilibrium state should be considered on the basis of $a_{\mathrm{SiO}_{2}}$ in slag. It should be, however, recognized through my present work that the deoxidation is greatly influenced by co-existing slag. This indicates that even at the stage that the oxygen concentration drops to apparently constant level (in this stage the motion of inclusions in the melt may be considered to be ruled by Brownian motion), the sluggish deoxidation (or oxidation) proceeds on the slag-melt interface. In short, this is the problem on the kinetic view.

In our study, the pick up of $\mathrm{Al}$ is also identified as 
you suggested, but in this case, this reaction has been also governed by the slag basicity of co-existing slag and can be explained on the basis of silica activity. The oxygen value in the actual stainless steel melting practice only by silicon deoxidation also indicated that the oxygen was reduced roughly in proportion to $\mathrm{Si}$ content and that this value was apparently influenced by $a_{\mathrm{SiO}_{2}}$ in the slag after the favorable slag-melt mixing by tapping.

As mentioned above, it may be right to evaluate the oxygen value thermochemically from the solute elements which are responsible to lower $a_{\mathrm{SiO}_{2}}$ as you pointed out, it is, however, difficult to determine the equilibrium state because of lack of the thermochemical values and the difficulties in the chemical analysis of minor element such as Ca or Al. So, we considered the effects of slag or refractory conveniently for the evaluation of the equilibrium state and could explain the phenomenon of the deoxidation by $\mathrm{Si}$ in stainless melt fairly well. 